\title{
KAPITALENS VILDTLEVENDE RINGVIRKNINGER
}

\section{ANNE-SOFIE LAUTRUP SøRENSEN}

\section{Første forsøg: overvældelse}

Mit første dyk ind i Feral Atlas er en blandet fornøjelse. Jeg går til Feral Atlas med samme tankesæt, som jeg typisk går til en akademisk artikel med: Hvad er argumentet? Resultatet er overvældende. I takt med at jeg mister overblikket, vokser min modstand mod værket, som synes umuligt at overskue. Jeg klikker mig rundt mellem billeder, kort, videodigte, feltrapporter og får fornemmelsen af, at alt er forbundet, men at forbindelsernes måde at være forbundne på undslipper mig. Hvad vil det her værk fortælle mig?

\section{Andet forsøg: analog æstetik i et digitalt værk}

Andet forsøg er bedre. Jeg dvæler ved åbningssiden, hvor akvarellignende billeder flyder rundt på en hvid baggrund. Der er noget ved billedernes analoge æstetik, der overrasker mig. Hvad laver de her, i et digitalt værk? Billederne konfronterer mig med mine forventninger til den digitale verden: 3D, udvidet virkelighed, hastighed. De her billeder flyder i rolige bevægelser ind på skærmen, bevæger sig lidt rundt på den og ud igen. Nye billeder kommer til, andre forsvinder. Det eneste stabile element: en lille roterende 3D-nøgle i øverste venstre hjørne. Jeg får det indtryk, at billederne bebor deres egen verden, som skærmen blot er et vindue ind til. Og vigtigere: Deres bevægelsesmønster henvender sig ikke til mig. Jeg googler, hvordan man oversætter feral til dansk. Vildtlevende foreslår google translate. Jeg begynder at tænke på akvarellerne som vildtlevende væsener i en digital verden. 


\section{Jeg trykker på „carbon dioxide“}

Jeg fører musen hen over nogle af billederne: „Bd cythrid funghus“, „Sea fire“, „Fukushima woodchips“. Hvert billede er forbundet til en facet: invasion, imperium, kapital eller acceleration. Jeg trykker på et billede af to skorstene med titlen „Carbon dioxide“ og forbindelse til facetten kapital. Det er et oplagt valg med tanke på min igangværende ph.d. om, hvordan $\mathrm{CO}_{2}$-data bliver mobiliseret i lokale konflikter om klimakrise og olieindustriens fremtid i den norske olieby Stavanger. Skærmen bliver sort. I midten af det sorte former en hvid sky sig. Skyen vokser, indtil den fylder hele skærmen og afslører derefter et gråt by- og industrilandskab. Det hele ser meget ordentligt ud ved første øjekast: lige linjer. Men ved nærmere eftersyn opdager jeg, at nogle af husene står skævt og har huller $i$ tagene. Nede ad en vej ligger biler spredt ud hulter til bulter og ligner efterladte legetøjsbiler. De to skorstene, jeg trykkede på, er også en del af byen. De er meget store og ligger lige ved siden af en gade, hvor en gruppe mennesker går i et protesttog med vajende faner og et banner. Jeg zoomer ind og ser, at der står „STRIKE“ på banneret. En gulgrøn røg ligger over skorstenene, og i røgen er en rød prik. Jeg fører cursoren over prikken og læser „,carbon dioxide from burning fossil fuels“. Jeg trykker og befinder mig nu på en ny side. Her bliver jeg mødt af nogle videodigte, der viser dragende klip af de enorme infrastrukturer, hvor fossile brændstoffer udvindes og behandles. Brutale metalkonstruktioner og en rød flamme. En pumpes monotone vuggen mod himmelen. Jeg klikker mig videre til en feltrapport bestående af tekst og tegninger, der undersøger karbondioxid som et vildtlevende element: Fra at have været en del af en livgivende balance har mængden af kuldioxid bevæget sig ud af kontrol igennem en kapitalismedrevet afhængighed af fossile brændstoffer.

Jeg trykker mig tilbage til kortet og finder ud af, at cursoren bliver til en lille hånd, når jeg trykker på kortet. Jeg bevæger den lille hånd med musen, kortet følger med og afslører nye dele af byen. Et stænk af blågrøn fanger mit blik i udkanten af det grå. Begejstret trækker jeg i kortet for at finde ud af, hvad der folder sig ud bag farven. Havet. Og derefter en olieboreplatform. Der er en prik på platformens ene ben: „Jellyfish polyps on marine infrastructure.“ Gennem en række klik lærer jeg, at bestanden af gopler i Adriaterhavet er steget markant i takt med udbredelsen af installationer som offshoreboreplaforme. Platformenes hårde benkonstruktioner tilbyder langt bedre betingelser for goplepolypper at fæstne sig og udvikle nye gopler end dem, der findes fra naturens hånd. 


\section{Det digitale format: formen som argument}

Værket tager sin læser med tæt på de fysiske infrastrukturer, som er en del af kapitalismens skelet. Store skorstene, tykke og lange rør, olieboreplatforme. Gitteropdelte plantager og fyldte containerskibe. På den måde tydeliggør Feral Atlas, at der er materialitet og konkrete steder bag kapitalismens produkter og virkemåde. Samtidig inviterer værket sin læser til at undersøge de forbindelser, den fysiske infrastruktur har til mere-end-menneskelige væsener som gopler og gasser.

Værket tydeliggør fysisk infrastruktur gennem sin egen digitale infrastruktur. På min vej rundt i værket, vokser et spørgsmål frem i mig: Kan Feral Atlas' evne til at overvælde forstås, som at atlasset er ,gone feral“"? Udgør værket et eksempel på, hvordan et vildtlevende akademisk værk kan opføre sig? Et værk, der har forladt boghylden, er blevet til noget andet - noget, der vækker modstand, når man som læser leder efter hovedargumentet, men gavmildt åbner sig, når man overgiver sig til at miste overblikket. Netop i overgivelsen til det overvældende kommer et argument alligevel til syne i Feral Atlas: Atlasset gør sit argument. Formen på værket og læserens vej gennem det reflekterer den overvældende mængde af forbindelser mellem dyr, mennesker, teknologi og infrastruktur, der kendetegner den kapitalistiske verden. Det er enkelt at læse sig til denne information i beskrivelsen af værket på dets landingsside, men noget andet at erfare den på sin vej gennem værket. Den digitale infrastruktur gør det muligt for læseren at navigere i værkets mange lag af formater - video, tekst, kort, tegninger og billeder - og selv udforske den mangfoldighed af forbindelser, værket stiller til rådighed.

\section{Rejsefeber i en onlineverden af forbindelser}

Jeg ser mig selv rejse rundt $\mathrm{i}$ atlassets onlineverden og tænker på denne rejses forhold til antropologiens generelle rejsefeber. En rejsefeber, der er uadskillelig fra det faktum, at disciplinen og dens kronjuvel, det etnografiske feltarbejde, er opstået med tæt forbindelse til kolonial dominans. Og at datidens antropologers adgang til koloniserede samfund ofte var bundet op på at skabe viden, der kunne bruges til at bevare kolonial kontrol. Det er en arv, der fortsætter med at have betydning for antropologien og de verdener, dens metoder og analyser er med til at skabe.

Atlasset mimer på sin vis det etnografiske feltarbejde i sin invitation til læseren om at bevæge sig nye steder hen og udforske temaer og forbindelser. Samtidig er der tale om en kurateret bevægelse ind i et onlineunivers skabt med udgangspunkt 
$i$ et bredt fagligt landskab, der strækker sig ud over antropologiens grænser. Der er ikke mulighed for som under et etnografisk feltarbejde at engagere sig med praksis for at nærme sig et svar på, hvorfor folk gør, som de gør. Der er ikke nogen mennesker at stille spørgsmål og bruge tid med. Men der er forbindelser at følge. Betegnelsen „,det antropocæne“ er blevet kritiseret for at implicere en ensartet menneskehed som motor for klimakrisen. I kraft af de forbindelser, det stiller til rådighed, formår Feral Atlas imidlertid både at have blik for det mere-endmenneskelige $o g$ at tegne et nuanceret billede af menneskene i det antropocæne. Værket minder om, at ansvar og sårbarhed ikke er ensartet fordelt, og tilbyder utallige eksempler på, at de vildtlevende aspekter ved det antropocæne vokser ud af en fortsat ulige akkumulering af kapital, der bygger på kolonial dominans, slavegjort arbejdskraft og plantagedrift såvel som udvinding af fossile brændstoffer. Sammenhænge, der også spiller en central rolle i den ulige distribution af den klimamæssige og økologiske krises konsekvenser. 